\title{
The Anthracite as Sinter Fuels
}

\author{
Michal Sikora, Petr Janík, \\ Pavlína Pustějovská, Simona Jursová \\ VSB-TUO, Technical University of Ostrava, Czech Republic
}

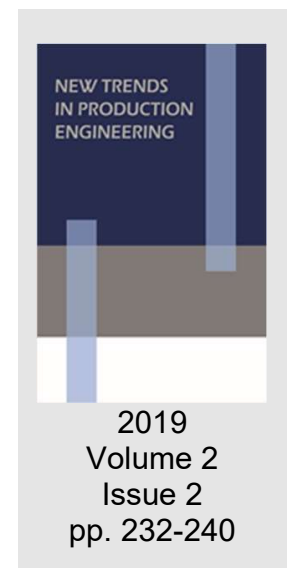

Date of submission to the Editor: 09/2019

Date of acceptance by the Editor: 11/2019

\section{INTRODUCTION}

\section{Metallurgy and blast furnace process}

The world's most important fuel-energy raw materials are coal, oil and natural gas. But stocks are constantly falling. Oil stocks are estimated to be only 50 years old, coal is 240 years old and gas is 80 years old.

Australia and China are world leaders in iron ore mining and mining. There are approximately 53,000 million tons of raw ore in Australia, let alone 23,000 in China (USGS Minerals Information, 2019).

Metallurgy research is focused on reducing the energy intensity of processes and environmental loads. The blast furnace charge consists of three main raw materials: fuel, iron ore and additives.A blast furnace is a closed system into which iron-bearing materials (iron ore lump, sinter and/or pellets), additives (slag formers such as limestone) (Baricová et al., 2013) and reducing agents are continuously fed from the top of the furnace shaft through a charging system that prevents escape of blast furnace gas. Fuel consumption in blast furnaces depends on many factors (Bernasowski et al., 2012). The blast furnace coke quality and quality of ferrous burden materials are important for the blast furnace process (Kardas, E., 2013, Konstanciak, A., 2015). The production of pig iron within the European Union is shown in Fig. 1.

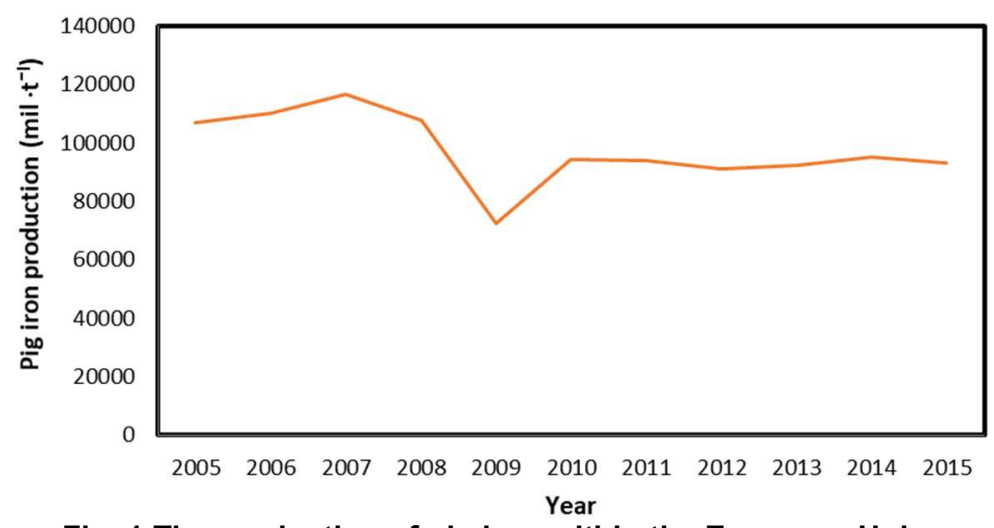

Fig. 1 The production of pig iron within the European Union 
The metallurgical companies use large amounts of energy for the production of steel. The iron and steel industry is highly intensive in both materials and energy (Ironmaking and Steelmaking. BAT, 2010). Almost half of the input ends up as off-gases, process gases and solid production residues. (Václavík et al., 2015, Pribulova et al., 2019).

In the Czech Republic, the fuel for sintering process is coke breeze, or pulverized coal, anthracite or oil. The comparison of the average parameters of anthracite and coke breeze is shown in Table 1.

Source: (Sikora, 2017)

Table 1 The comparison of the average parameters of anthracite and coke breeze

\begin{tabular}{|l|c|c|c|c|}
\hline & $\mathbf{H}_{2} \mathbf{O}(\mathbf{\%})$ & $\mathbf{S}(\mathbf{\%})$ & $\mathbf{V}^{\text {daf }}(\mathbf{\%})$ & $\mathbf{A}^{\mathbf{d}}(\mathbf{\%})$ \\
\hline Anthracite & 12.63 & 0.24 & 2.71 & 12.43 \\
\hline Coke breeze & 15.32 & 0.63 & 2.32 & 12.29 \\
\hline
\end{tabular}

Limestone or dolomite is used as flux and the iron ore usually gets into the blast furnace in the form of agglomerate or pellets.

Thus, the agglomerate is a major metal bearing component for the blast furnace. In most case, coke breeze is used as the fuel for sintering process. Coke has a high calorific value, low reactivity and a low volatile content. In recent years, brown coal coke, anthracite or also biomass have been used as fuel for sintering process (Findorák et al., 2013).

A comparison of the development of anthracite and coal prices is shown in Fig. $2,3$.

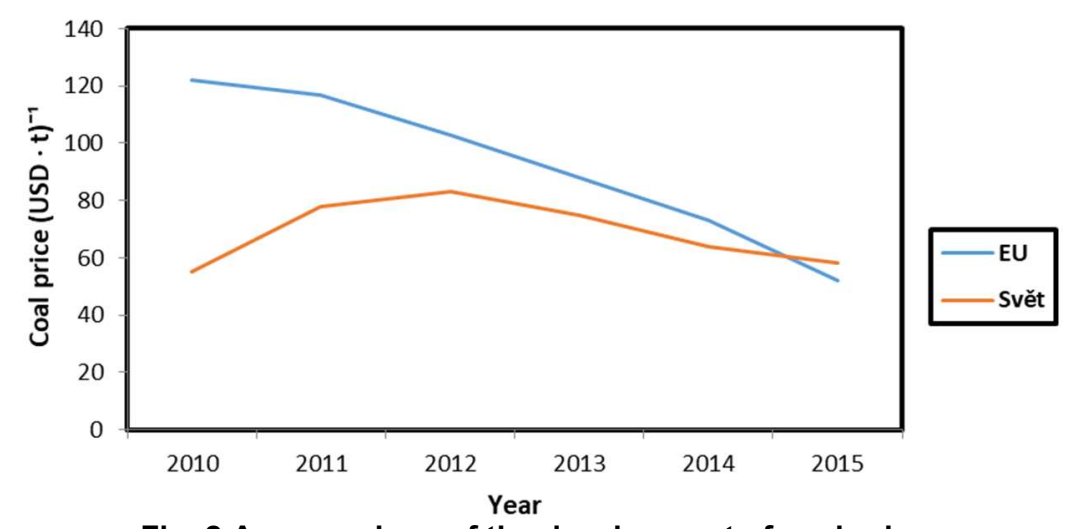

Fig. 2 A comparison of the development of coal prices

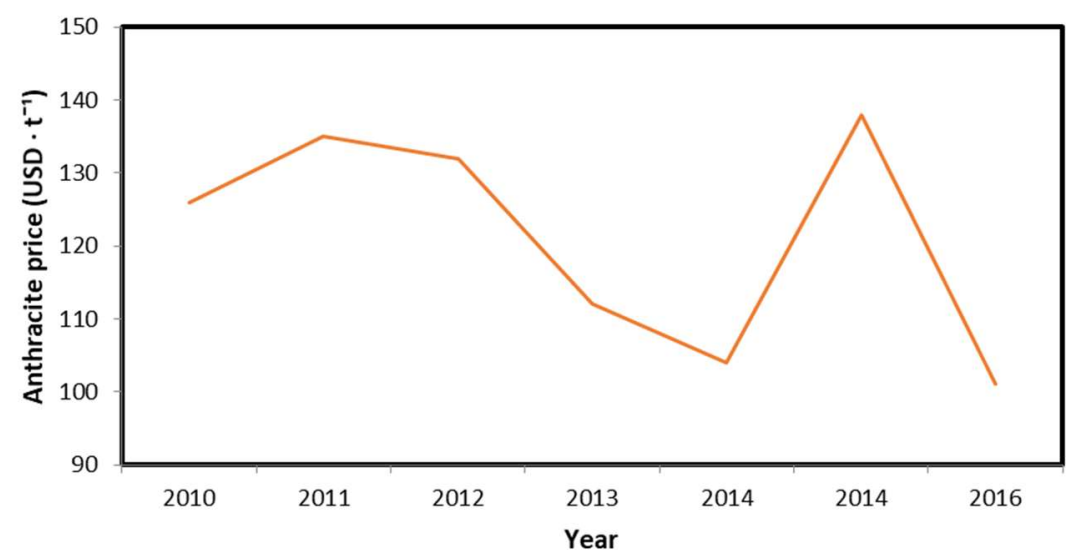

Fig. 3 A comparison of the development of anthracite prices 
The main emphasis must therefore be placed on economic and technological aspects of the use of secondary products (Brožová et al., 2014).

\section{Sintering process}

In the Ferrous Metallurgy the agglomeration of fine ferrous compounds, like fine ores as well as blast furnace, steel works waste, mill scale and dusts from electrostatic precipitators, is called the sintering process (Babich et al., 2008). The production of the agglomerate is a thermo-technical process where the heating of the materials is provided by carbonaceous fuel. Carbonaceous fuel is in most cases coke breeze, which is produced by metallurgical coke sorting (Fröhlichova, M. et al., 2015).

Coke breeze is the main fuel used in the sintering process. The value of $-3+1$ $\mathrm{mm}$. represents the most favourable particle size for coke breeze in the sintering process (Mohamed et al., 2010).

Alkaline additives should be below $3 \mathrm{~mm}$. Individual grains of alkaline additives are subject to dissociation in the first phase, in the second phase the $\mathrm{CaO}$ decomposition product must react, usually with $\mathrm{SiO}_{2}$ from the melted ore grain surface. Since these reactions last for some time, and the sintering process is rapid, the central portion of the original grain remains unreacted as free $\mathrm{CaO}$. This is reflected in white spots in the produced agglomerate. Lime absorbs moisture from the air and causes it to disintegrate. A high proportion of very fine particles (below $0.5 \mathrm{~mm}$ ) is not suitable for all components of the sinter batch. They have inferior wettability and increase dust emissions to air (Legemza et al., 2018).

During the iron ore sintering process, two types of particles are present in the sinter bed: (1) fines, which are actively taking part in melting and the formation of secondary phases, and (2) coarse ores, which are partially interacting with the surrounding melt. (Mezibricky et al., 2019)

\section{METODOLOGY OF RESEARCH}

Today, efforts are being made to improve the quality of the agglomerate by reducing fuel consumption. High-quality fuel for agglomerate production is finegrained coke dust or coke pulp. In recent years there has been a trend to replace coke dust with anthracite, so far only partially. Fuel is used for sintering with a grain size of less than $3 \mathrm{~mm}$. Basically it is a blast furnace coke that is ground to the abovementioned grain size. From a chemical point of view, this coke is subject to requirements such as:

- The non-volatile carbon content, which must be between 83-91\%;

- The content of volatile substances, the content of which depends on the degree of maturity of the coke;

- Sulfur content, sulfur in coke is mostly organic in origin, namely $65-80 \%$;

- ash content, in the case of the highest quality coke fuels, its content ranges up to $8-10 \%$, for common use about $10-14 \%$ ash; 
- phosphorus content. Phosphorus is generally regarded as an undesirable and harmful element in the production of pig iron. The phosphorus content of the coke for agglomeration depends on the phosphorus content of the coal charge, which is about $0.006-0.283 \%$.

Sintering of iron ores is characterized by high thermal, mineralogical and chemical unevenness, both over the height of the sintered mixture and in volumes. The grain size of the sintering components is very important as it affects the chemical composition of the pellets and the distribution of the solid fuel in the sintering layer, which causes unevenness temperature-kinetic sintering conditions. Granulometry is most important for the sintering, pelletizing and granulating process (Slíva et al., 2019).

The solid fuel that is added to the agglomerate has different fractions. Large solid fuel particles are not added to the mixture as this can lead to weaknesses in the structure of the agglomerate produced. In the whole agglomeration mixture there is an unevenness of chemical and mineralogical composition both in the feed mixture and in the finished agglomerate.

The first drops of melt are formed when the solid fuel reaches a temperature of 700 to $760^{\circ} \mathrm{C}$. Drops also appear around the return sinter fines and at the contact points of lime and hematite at a eutectic temperature of $1205^{\circ} \mathrm{C}$. The return sinter fines is a return fraction, sintered again and the amount is about $25 \%$. The return sinter fines has a favorable effect on sintering of the sintered mixture during sintering. It has a larger grain size than the micro-packs of the sintered mixture and also by heating the charge. In addition, it contains components that have already been sintered and therefore the heat consumption for sintering the return sinter fines is lower than for sintering the raw ore.

From the amount of return sinter fines it can be concluded whether the finished sinter is sufficiently strong or well reducible. Under operating conditions, it is determined that a weighing container is placed in the return sinter fines path and weighs the return sinter fines. If the amount of the resulting return sinter fines increases, this means that the strength of the finished sinter decreases and the reducibility increases and vice versa. When the weight of the return sinter fines in the container decreases, this means that the strength increases and the reducibility decreases.

The particles which are distributed in the sinter mix are arranged at a smaller distance than in the solids structure. The sinter mix is therefore unevenly distributed throughout its volume. Capillary bridges are formed faster in areas where gas flow is greater than in areas where gas flow is lower.

The structure of the sinter is very important, therefore research focuses on more detailed information, both in terms of mineralogical composition and mechanical properties of the sinter. An agglomerate is a sintered product having a certain porosity. Porosity is the total contact area of the solid particles expressed by the total or specific pore surface. Porosity significantly reduces the strength of the agglomerate.

The researchers (Bhagat, 2015) conducted research into reducing coke breeze in the sintering process. The yield and productivity of the finished agglomerate 
were investigated. With a basicity agglomerate of 2.5 and $1.5 \%$ and an $\mathrm{MgO}$ content, with a gradual decrease in coke by half, the yield improved by about $8 \%$, resulting in a better production productivity of about $30 \mathrm{t} \cdot \mathrm{m}^{-2}$ day. The cooling time was also reduced by less than 3 minutes due to the lower temperature of the sinter mixture and also due to the lower porous structure of the agglomerate.

Australian scientists (Liming et al., 2015) has investigated the relationship between structure and chemical composition, including basicity on agglomerate quality. When the basicity of the agglomerate increased, more binding phases were formed and this led to an improvement in the pore structure. The strength of the agglomerate was increased by increasing the basicity to 3 . When the basicity of the agglomerate increased up to 3.5, the strength fell sharply. Furthermore, it was found that the agglomerate strength improved with increasing content of $\mathrm{SiO}_{2}$ the increase of $\mathrm{SiO}_{2}$ had values from 4.5-6.5\%. The increase in $\mathrm{SiO}_{2}$ values led to an increase in the agglomerate strength, but large pores in the structure began to form. Research has also shown that with increasing $\mathrm{Al}$ content decreases, the same happens with $\mathrm{MgO}$ above $3 \%$.

Fuel flammability is another important parameter. The combustion moves as fast as the fuel in the mixture burns.

In the preparation of the sinter mix, the fuel is added at the pre-pelletization stage, where the task is to create micro pellets, which are needed to ensure perfect air permeability of the charge. In order to create micro pellets a liquid is needed, here water is used.

In order to burn fuel, the mixture must be ignited on the sintering belt. Burners having a flame temperature of about $1000^{\circ} \mathrm{C}$ are commonly used. It is used coke oven or top gas, it is also possible to use gas generator type. As soon as the mixture ignites, it gradually burns in the so-called small sintered layer (Stecko et al., 2017). During combustion, the oxygen content is constantly reduced and the $\mathrm{CO}$ and $\mathrm{CO}_{2}$ content of the combustion products increases. Once the sintering is complete, the process is reversed: oxygen increases and the flue gas content ( $\mathrm{CO}$ and $\mathrm{CO}_{2}$ ) decreases.

The most used fuel for the sinter feedstock is coke dust, anthracite and semicoke, but increasingly, substitute fuels, such as biomass, are coming to the fore. The fuel must have certain energy-emission limits and should be neutral with respect to greenhouse gases (Fröhlichova, M. et al., 2018).

Production of agglomerate in the metallurgical company belongs among the largest sources of emissions damaging the environment. Effects of coke breeze substitution by charcoal, pine, and oak sawdust there were sintering performed in a laboratory agglomeration pan with substitution ratios of $14 \%$ and $20 \%$ by the emissions of $\mathrm{CO}_{2}, \mathrm{CO}, \mathrm{NO}$ and $\mathrm{NO}$ (Lesko et al. 2017).

Researchers in Asia (Jiang, T., et al. 2010) are introducing a completely new method, known as CAP, where it involves total or partial separation of ores (8$16 \mathrm{~mm}$ ) in a drum and the remainder of the ore is pelleted after the first mixing with the return of the return sinter fines, fuel and additives. 
Thereafter, this mixture is passed to a secondary mixing and this is combined with a second mixing stage. Advantages include: increased sinter production, reduced energy consumption, use of different ore sizes, possibility to prepare sinter with low basicity and high reducibility.

\section{RESULTS}

The fuel for sintering charge is very important as it provides enough heat to the physical and chemical processes and the formation of agglomerates of desirable properties. Iron ore gets into the blast furnace either with agglomerate (about $65 \%$ ) or pellets (about $30 \%$ ). Both concentrates and hematite dust ores are imported into the Czech Republic. Usual composition: $\mathrm{Fe}_{\text {total }}=63-67 \% ; \mathrm{Al}_{2} \mathrm{O}_{3}$ max. $1.2 \% ; \mathrm{SiO}_{2}=3.5-6.0 \% ; \mathrm{Mn}=0.1-0.3 \% ; \mathrm{P}$ below $0.04 \% ;\left(\mathrm{K}_{2} \mathrm{O}+\mathrm{Na}_{2} \mathrm{O}\right)=$ $0.05-0.08 \%$.

For dust agglomeration ores used in the Czech metallurgical plant, the contents of the undesirable coarse fraction above $10 \mathrm{~mm}$ are usually about $7 \%$, as shown in Table 2.

Table 2 Composition of fine iron ores

\begin{tabular}{|c|c|c|c|c|c|c|}
\hline & $\begin{array}{c}F_{\text {total }} \\
(\%)\end{array}$ & $\begin{array}{l}\mathrm{SiO}_{2} \\
\mathrm{Al}_{2} \mathrm{O}_{3}\end{array}$ & $\begin{array}{l}\mathrm{CaO} \\
\mathrm{MgO}\end{array}$ & $\begin{array}{c}\mathrm{K}_{2} \mathrm{O}+\mathrm{Na}_{2} \mathrm{O} \\
(\%)\end{array}$ & \multicolumn{2}{|c|}{$\begin{array}{c}\text { Grain size \% } \\
\langle 0,5 〉 10 \mathrm{~mm}\end{array}$} \\
\hline Krivbas & $57-61$ & $\begin{array}{c}10-16 \\
0.9-1.1\end{array}$ & $\begin{array}{l}0.1-0.2 \\
0.1-0.3\end{array}$ & $0.1-0.2$ & $20-24$ & $<12$ \\
\hline $\begin{array}{l}\text { Suchá } \\
\text { Balka }\end{array}$ & $59-60$ & $\begin{array}{c}11-13 \\
0.8-1.2\end{array}$ & $\begin{array}{c}0.14 \\
0.1-0.3\end{array}$ & $0.2-0.24$ & $35-37$ & $<15$ \\
\hline Zaporož. & 62 & $\begin{array}{c}7-8 \\
1\end{array}$ & $\begin{array}{l}0.4-0.6 \\
0.2-0.3\end{array}$ & $0.06-0.1$ & $20-23$ & $\ll 10$ \\
\hline
\end{tabular}

Source: (Sikora, 2017)

Table 3 Composition of iron ore concentrate

\begin{tabular}{|c|c|c|c|c|c|c|}
\hline & $\begin{array}{c}\text { Fetotal } \\
(\%)\end{array}$ & $\begin{array}{l}\mathrm{SiO}_{2} \\
\mathrm{Al}_{2} \mathrm{O}_{3}\end{array}$ & $\begin{array}{l}\mathrm{CaO} \text {, } \\
\mathrm{MgO}\end{array}$ & $\begin{array}{c}\mathrm{K}_{2} \mathrm{O}+\mathrm{Na}_{2} \mathrm{O} \\
(\%)\end{array}$ & \multicolumn{2}{|c|}{$\begin{array}{c}\text { Grain size \% } \\
\iota 0,5 \triangleleft 10 \mathrm{~mm}\end{array}$} \\
\hline Jugok & $>64.5$ & $\begin{array}{l}8-9 \\
0.1\end{array}$ & $\begin{array}{c}0.15 \\
0.4\end{array}$ & >.15 & 8 & 8 \\
\hline Kordov. & >63.6 & $\begin{array}{c}>0.67 \\
1.8\end{array}$ & $\begin{array}{l}0.3 \\
5.5\end{array}$ & $>0.12$ & 15 & 48 \\
\hline Stojlens. & $>66$ & $\begin{array}{l}6-7 \\
0.2\end{array}$ & $\begin{array}{c}0.2 \\
0.45 \\
\end{array}$ & $>0.2$ & 47 & 10 \\
\hline Lebedin. & >67 & $\begin{array}{l}4-5 \\
0.15 \\
\end{array}$ & $\begin{array}{l}0.2 \\
0.3 \\
\end{array}$ & $>0.1$ & 51 & 9 \\
\hline Cegok & $64-65$ & $\begin{array}{c}8.8-9.9 \\
0.35\end{array}$ & $\begin{array}{l}0.19 \\
0.32 \\
\end{array}$ & $>0.12$ & 9 & 11 \\
\hline Sevgok & 65 & $\begin{array}{c}8.7 \\
0.17\end{array}$ & $\begin{array}{l}0.37 \\
0.43 \\
\end{array}$ & $>0.1$ & 13 & 4 \\
\hline Ingulec & 64 & $\begin{array}{l}8-9 \\
0.5\end{array}$ & $\begin{array}{l}0.26 \\
0.74 \\
\end{array}$ & >.14 & 62 & 10 \\
\hline
\end{tabular}

Source: (Sikora, 2017)

The best-known of the monitored indicators was specific performance. Comparisons in individual years and for coke and anthracite are shown in Fig. 4. 


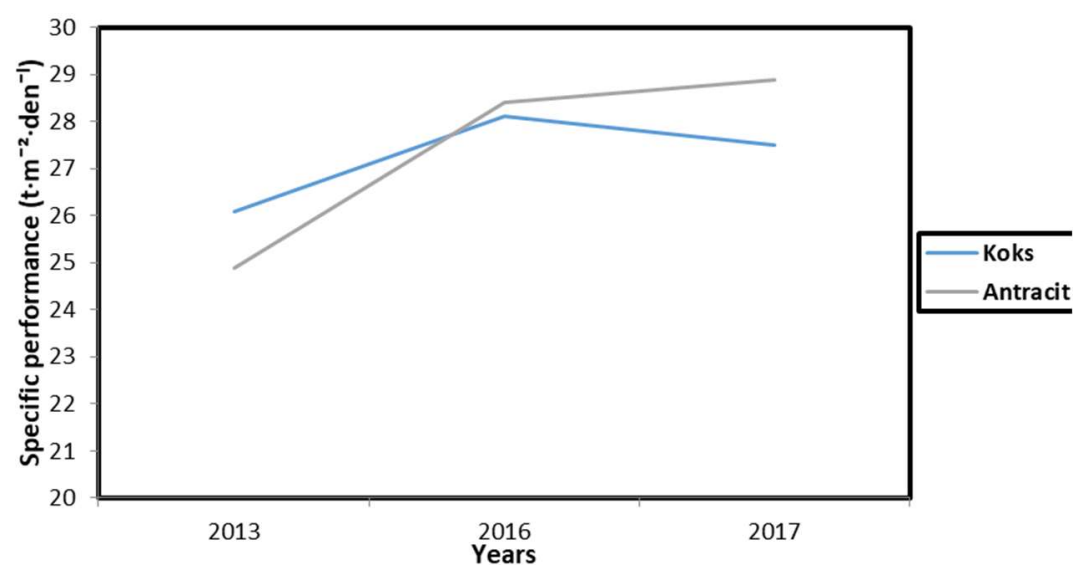

Fig. 4 Comparisons in individual years and for coke and anthracite

\section{DISCUSSION}

The results can be formulated:

- If $100 \%$ coke content is replaced by anthracite, agglomerate production decreases by $17 \%$;

- Replacement of coke with anthracite does not compromise the process of packing and pre-pelletizing the sinter mix. As the coefficient of coke replacement by anthracite increased, the sintered layer temperatures decreased and the sintering time increased. The substitution of coke by anthracite had a slight decrease in the proportion of the sub-network by about $2 \%$ in the case of extreme substitutions, which was confirmed by an increase in the medium grain;

- The strength of the agglomerates was on average identical with a slight negative influence of anthracite, which resulted in an increase in abrasion by approx. $0.7 \%$;

- In the case of $50 \%$ substitution, more positive performance parameters with anthracite were demonstrated than with standard sintering with coke;

- In terms of emissions, there has been an increase in $\mathrm{CO}$ and $\mathrm{CO}_{2}$ contents, which shows us a deterioration of fuel burning conditions in terms of a decrease in perfect combustion, and this has resulted in lower temperatures in the sintered layer.

\section{CONCLUSION}

The basic component of the blast furnace charge within the Moravian-Silesian Region is the agglomerate, whose production is still one of the few technologies used in the processing of fine-grained metal-bearing materials. However, the use of fine metallurgical waste in the sintering of iron ores causes, in addition to environmental problems, technological problems, and an increased proportion of dust particles in the mixture worsens the permeability of the mixture and reduces the sintering rate. While sintering, some of the harmful elements are removed, but part of it goes into the atmosphere.

The evaluation of the properties of the agglomerate is currently important in terms of quality control of blast furnace charge materials. Complex evaluation of the resulting agglomerate can be used both for controlling the blast furnace 
process technology itself and for controlling the agglomerate production process. The resulting properties of the agglomerate produced depend on a large number of factors. The most important is the effect of carbonaceous fuel on the final product/agglomerate. The type of fuel used affects the final properties of the agglomerate as well as the economic and ecological conditions of its production.

Operational testing of anthracite replacement of coke dust has shown that the anthracite enforcement significantly affects both the economy and the environment. The addition of anthracite (about $15 \mathrm{kt}$ ) proves to be optimal for coke saving in the sintering process.

\section{ACKNOWLEDGEMENT}

This work was carried out in the support of projects of "Student Grant Competition" numbers SP2019/148 and SP2019/160.

\section{REFERENCES}

Babich, A. et al. (2008) Ironmaking. RWTH Aachen University, Department of Ferrous Metallurgy, Wissenschaftsverlag Mainz in Aachen.

Baricova, D., et al. (2013) Steelmaking slag-waste or valuable secondary raw material. In International Multidisciplinary Scientific GeoConference Surveying Geology and Mining Ecology Management, SGEM, Albena, [online], pp 437-442.

Bernasowski, M.,Klimczyk, A. and Stachura, R. (2019) Support algorithm for blast furnace operation with optimal fuel consumption. Journal of mining and metalurgy section B-metallurgy. 55 (1), pp. 31-38.

Bhagat, P, R. (2015) Reduction of solid fuel consumption in sintering of indian iron ore. Science of Sintering, 47, pp. 205-213.

Brožová. S., Pustějovská. P., Jursová. S. and Ingaldi. M. (2014). Economic and technological aspects of the use of secondary metal - bearing raw materials for metallurgical production. In: Metal 2014. Brno [online]. Volume 23. pp. 1-5. Available at: http://konsys-t.tanger.cz/files/proceedings/17/reports/2865.pdf [Accessed 17. July 2019]Ironmaking and Steelmaking. Best Available Techniques. 2010/75/EU 2010.Available http://eippcb.jrc.ec.europa.eu/reference/BREF/I\&S/IS_Published_0312.pdf [Accessed 18. July 2019]

Findorak R., et al. The effect of charcoal addition on iron-ore sintering emission. International Multidisciplinary Scientific GeoConference Surveying Geology and Mining Ecology Management, SGEM, Albena, Bulgaria, 2013, pp 629-636.

Fröhlichova,M., Ivanisin, D.,Findorak, R., Dzupkova, M. and Legemza, J. (2018). The Effect of Concentrate/Iron Ore Ratio Change on Agglomerate Phase Composition. METALS. 8 (11), pp. 234-239.

Jiang, T., Wang, H. T. and Zhang K. C.(2010) Composite agglomeration process (CAP) for preparing blast furnace burden. Ironmaking and Steelmaking, Proces products and applications, Vol. 37( 1), pp. 1-7.

Kardas, E. (2013) The analysis of quality of ferrous burden materials and its effect on the parameters of blast furnace process. Metalurgija, 52(2), pp.149-152. Konstanciak, A. (2015) Evaluation of the valuation of the quality of coke for blast furnace process in chosen metallurgical plant. In: Metal 2015. Brno [online]. pp. 1988-1993.

Legemza J., Fröhlichova, M. and Findorak,R. (2018) The influence of biomass on ecological aspects of ferriferrous agglomerate production. International Multidisciplinary Scientific GeoConference Surveying Geology and Mining Ecology Management, SGEM, Albena, Bulgaria, pp. 187-194. 
Lesko, J. Hudak, J. and Semanova, Z. (2017) Impact of Biofuel in Agglomeration Process on Production of Pollutants. Science of Sintering, 49, pp. 159-166.

Mezibricky, R.Frohlichova, M., and Findorák, R. Ore Assimilation and Secondary Phases by Sintering of Rich and High-Gangue Iron Ores. Minerals, vol 9, issue 2, article number 128, 2019.

Liming, L., Ware, N. and Raynlyn, T. (2015) Chemistry structure and quality of iron ore sinter. AISTech 2015 Proceedings, pp. 322-332.

USGS Minerals Information: Publications and Data Products. [online]. Available at: https:// minerals.usgs.gov/minerals/pubs/ [Accessed 12 May 2019]

Mohamed, F.,M., El-Hussiny, N.A. and M. E. H. Shalabi. (2010) Granulation of Coke Breeze Fine for Using in the Sintering Process. Science of Sintering, 42, pp. 193202.

Pribulova, A., Baricova, D., Futas, P., Pokusova, M., and Eperjesi, S. (2019) Cupola Furnace Slag: Its Origin, Properties and Utilization. International Journal of Metal Casting, 13(3), pp. 627-640.

Sikora M., Verification of operation of experimental sinter pot for sinter preparation, Diploma thesis, Czech Republic, Ostrava: VŠB-TUO, 2017, 58 pp.

Slíva A., et al. Study of the Optimum arrangement of spherical particles in containers having different cross section shapes. Journal of Nanoscience and Nanotechnology. Vol 19/ issue 5, pp 2717-2722, 2019.

Stecko J., et al. Utilisation of metallurgical sludge by multi-layer sintering. Ironmaking and Steelmaking, pp. 1-8, 2017

Václavík V., et al. Steel Slag as a Substitute for Natural Aggregate in the Production of Concrete. Solid State Phenomena, pp. 77-87, 2015.

\begin{abstract}
.
The chapter deals with the use of traditional carbonaceous fuels in the production of agglomerates. An important part is focused primarily on the use of these carbonaceous fuels in the production of various types of agglomerate. Anthracite together with coke breeze was tested as a fuel to assess the substitution of coke dust by anthracite for technological and qualitative parameters of sintering.
\end{abstract}

Keywords: coke breeze, anthracite, sinter 